\title{
Kegagalan Komunikasi Politik Dinasti dalam Pemilukada Kota Serang 2018
}

\author{
Indrianti Azhar Firdausi ${ }^{*}$, Ahmad Sururi ${ }^{2}$ \\ 1,2Prodi Ilmu Komunikasi, Universitas Serang Raya \\ J1. Raya Serang-Cilegon Km. 5, Taman Drangong, Serang - Indonesia \\ *Email korespondensi: indriantiazhar@gmail.com
}

\begin{abstract}
Abstrak
Penelitian ini membahas komunikasi politik pasangan calon Walikota dan Wakil Walikota Kota Serang: Vera dan Nurhasan yang berasal dari dinasti politik di Provinsi Banten. Pasangan tersebut percaya diri maju dalam kontestasi pemilihan umum walikota Serang tahun 2018 karena mendapat dukungan dari sejumlah partai besar dan beberapa pihak. Namun hasil akhir pemilihan, Vera-Nurhasan kalah. Hal tersebut disebabkan sebagai komunikator politik mereka belum matang dalam berpolitik. Pesan politik mereka dianggap tidak tepat dengan jargon "Menuju Kota Serang Cantik" di tengah kesemrawutan infrastruktur kota. Masyarakat kota yang rasional tidak memilih calon walikota dari keluarga dinasti. Penelitian ini menggunakan metode studi kasus dengan teori realitas sosial. Paradigma penelitian yang digunakan adalah interpretatif dengan pendekatan kualitatif. Teknik pengumpulan data dilakukan melalui wawancara dan observasi.
\end{abstract}

Kata kunci: Pilkada, Dinasti politik, Realitas sosial, Komunikasi politik, Provinsi Banten.

\section{PENDAHULUAN}

Pemilihan umum kepala daerah (Pilkada) Kota Serang tahun 2018 merupakan pesta demokrasi rakyat yang diikuti tiga pasang calon untuk memperebutkan jabatan walikota dan wakil walikota. Tiga pasang calon tersebut adalah pasangan Vera-Nurhasan yang didukung delapan partai politik; pasangan Samsul Hidayat-Rohman dari jalur independen, dan pasangan Syafrudin-Subadri yang berlatar belakang birokrat/politisi.

Sejumlah kejutan mewarnai hasil penghitungan cepat (quick count) dan sistem informasi perhitungan suara (situng) Komisi Pemilihan Umum (KPU). Di antara kejutan tersebut adalah kekalahan pasangan Vera-Nurhasan. Pasangan ini diidentikkan sebagai petahana dan didukung delapan partai politik. Perolehan suara mereka jauh dari pasangan calon nomor tiga, SyafruddinSubadri yang didukung empat partai politik.

Pasangan Vera-Nurhasan sejak awal diunggulkan. Elektabilitasnya tertinggi di antara dua calon lainnya, namun justru menelan kekalahan. Kemenangan pasangan Syafrudin-Subadri yang meraih suara 38.69 persen juga mengejutkan sebab bisa melewati perolehan suara Vers-Nurhasan. Syafrudin merupakan mantan birokrat di Pemerintahan Kota Serang, sementara Subadri merupakan mantan politisi dari Golkar yang dipecat beberapa waktu lalu. Sementara itu, perolehan suara pasangan calon dari jalur independen, Samsul Hidayat-Rohman, meski berada di posisi ketiga, mereka meraih dukungan signifikan, 82.030 suara (29.16 persen).

Partisipasi pemilih juga di luar dugaan, mencapai 69.62 persen dari daftar pemilih tetap (DPT) yakni sebanyak 433.077 jiwa. Pencapaian tersebut tertinggi dalam sejarah Pilkada Kota Serang.

Dalam perhelatan pemilihan kepala daerah di Banten, untuk pertama kalinya anggota keluarga dinasti politik Tb. Chasan Sochib gugur. Pasangan calon Wali Kota Serang, Vera Nurlaela-Nurhasan gagal dalam pertarungan. Vera merupakan istri Wali Kota Serang Tb. Haerul Jaman yang merupakan putra almarhum $\mathrm{Tb}$. Chasan Sochib, seorang tokoh masyarakat Banten yang sangat disegani pada masa hidupnya. 
p-ISSN: 0853-4470 - Vol. 02, No. 01 (2019), pp. 54-60

Sejak pemilihan umum kepala daerah dilakukan secara langsung, dinasti politik Tb. Chasan Sochib selalu memenangi pertarungan di sejumlah kabupaten/kota di Provinsi Banten. Ratu Atut Chosiyah, kakak tiri Tb. Haerul Jaman terpilih sebagai Gubernur Banten untuk dua periode. Namun pada periode kedua, Atut tersangkut kasus suap sengketa Pilkada Kota Serang.

Pada pertarungan Pilkada Kabupaten Serang, Ratu Tatu Chasanah, adik Ratu Atut berpasangan dengan Ahmad Taufik Nuriman berhasil menduduki kursi Wakil Bupati Serang. Kemudian berpasangan dengan Panji Tirtayasa, Ratu Tatu berhasil menduduki kursi Bupati Serang. Di Pilkada Kota Tangerang Selatan, Airin Rachmi Diany, istri Wawan Chaeri Wardana, adik Ratu Tatu Chasanah berhasil menduduki kursi Walikota Tangsel untuk dua periode, sementara itu Tb. Haerul Jaman memenangi pertarungan Pilkada Walikota Serang tahun 2013. Pada Pilgub Banten 2017, Andika Hazrumy, anak Ratu Atut Chosiyah, berpasangan dengan Wahidin Halim mengalahkan pasangan Rano Karno-Embay Mulya Syarief.

Kalahnya Vera dalam Pilkada Kota Serang mengejutkan banyak kalangan dan menimbulkan persepsi yang beragam. Vera gagal mempertahankan tangkup kekuasaan dinasti politik di Kota Serang. Dia tidak berhasil meraih kursi walikota yang ditinggalkan suaminya yang sudah menjabat dua periode.

Berdasarkan uraian di atas maka permasalahan penelitian ini adalah membahas kegagalan komunikasi politik dinasti Tb. Chasan Sochib pada pilkada Kota Serang tahun 2018.

\section{KERANGKA TEORI}

Politik dan komunikasi saling terkait dalam suatu pembicaraan tentang kekuasaan, pengaruh, otoritas/wewenang, dan konflik. Esensi komunikasi politik terkait dengan interaksi sosial dan konflik sosial. Nimmo (dalam Riswandi, 2009) merumuskan komunikasi politik sebagai kegiatan yang bersifat politis atas dasar konsekuensi aktual yang mengatur prilaku manusia.

Ruang lingkup komunikasi politik meliputi komunikator politik, pesan-pesan politik, media komunikasi politik, dan akibat-akibat komunikasi politik. Kegiatan komunikasi politik bertujuan untuk mengharmoniskan dan menjamin keberlanjutan sistem politik secara berkesinambungan yang akan mengayomi seluruh elemen dan anggota sistem politik tersebut.

Maswadi Rauf (dalam Harun \& Sumarno, 2006: 3) menyebutkan, komunikasi sebagai kegiatan politik merupakan penyampaian pesan-pesan yang bercirikan politik oleh aktor-aktor politik kepada pihak lain. Kegiatan komunikasi politik tersebut dapat bersifat empirik maupun ilmiah. Rusadi Kantaprawira (dalam Harun \& Sumarno: 2006, 3) menyatakan komunikasi politik ada untuk menghubungkan pikiran politik yang hidup dalam masyarakat, baik pikiran intern golongan, instansi, asosiasi, ataupun sektor kehidupan politik pemerintah.

Dalam komunikasi politik terdapat unsur-unsur yang terdiri dari komunikator politik (penyampai pesan), message (pesan), komunikan (penerima pesan), komunikan (penerima pesan). Dan Nimmo melibatkan unsur-unsur komunikasi politik dalam kajiannya, seperti komunikator politik, pesan politik, media politik, khalayak politik, serta akibat-akibat komunikasi politik.

Penelitian ini fokus menjabarkan komunikator politik dan pesan politik dari pasangan calon dinasti Vera-Nurhasan. Komunikator dalam proses komunikasi politik memainkan peran sebagai pembentuk opini publik, sedangkan pesan adalah pembicaraan-pembicaraan sebagai proses negosiasi yang bertujuan membentuk pengertian bersama antara pihak tentang bagaimana siap seharusnya yang harus diperankan setiap pihak dan bagaimana bertindak terhadap sesama. Dari sini, isi komunikasi politik tidak hanya berkaitan dengan kekuasaan tetapi juga kemungkinan terjadi konflik (Ali, 1999:132) 
p-ISSN: 0853-4470 - Vol. 02, No. 01 (2019), pp. 54-60

Teori yang digunakan dalam penelitian ini adalah teori realitas sosial Berger dan Luckmann. Konstruksi sosial atas realitas menggambarkan proses sosial melalui tindakan dan interaksi di mana individu menciptakan suatu realitas yang dimiliki dan dialami bersama secara subjektif (Bungin, 2006:193).

Asal mula konstruksi sosial dari filsafat konstruktivisme dimulai dari gagasan-gagasan konstruktif kognitif. Max Weber melihat realitas sosial sebagai perilaku sosial yang memiliki makna subjektif, karena itu perilaku yang mempunyai tujuan dan motivasi. Perilaku sosial itu menjadi 'sosial' jika subjektif dari perilaku sosial membuat indidvidu mengarahkan dan memperhitungkan kelakuan orang lain dan mengarahkan kepada subjektif tersebut. Perilaku tersebut memiliki kepastian kalau menunjukkan keseragaman dengan perilaku pada umumnya dalam masyarakat (Veeger dalam Bungin, 2006:192).

Menurut Berger dan Luckmann, realitas adalah pengetahuan yang bersifat keseharian yang hidup dan berkembang di masyarakat, seperti konsep, kesadaran umum, wacana publik, sebagai hasil dari konstruksi sosial. Realitas sosial dikonstruksi melalui proses eksternalisasi (penyesuaian diri) dengan dunia sosiokultural sebagai produk manusia, objektivasi, yaitu interaksi sosial yang terjadi dalam dunia intersubjektif yang dilembagakan atau mengalami proses institusionalisasi, sedangkan internalisasi yaitu proses dimana individu mengidentifikasikan dirinya dengan lembaga-lembaga sosial atau organisasi sosial tempat individu menjadi anggotanya. Konstruksi sosial tidak berlangsung dalam ruang hampa namun sarat kepentingan-kepentingan (Bungin, 2006;196-197).

Tiga tahapan proses dialektika pemahaman realitas disebutkan, pertama, eksternalisasi yaitu usaha pencurahan atau ekspresi diri manusia ke dalam dunia sosialnya, baik dalam kegiatan mental maupun fisik, dalam proses inilah dihasilkan suatu dunia dengan kata lain manusia menemukan dirinya sendiri dalam suatu dunia. Dengan demikian, tahap eksternalisasi ini berlangsung ketika produk sosial tercipta di dalam masyarakat, kemudian individu mengeksternalisasikan (penyesuain diri) ke dalam dunia sosiokulturalnya sebagai bagian dari produk manusai. (Bungin, 2006:198).

Kedua, objektivasi, merupakan hasil yang diciptakan oleh manusia berupa mental maupun fisik. Hasil tersebut merupakan realitas objektif yang dapat dimanfaatkan oleh manusia itu sendiri. Alat dan bahasa yang diciptakan adalah kegiatan eksternalisasi manusia ketika berhadapan dengan dunia dan menjadi produk eksternalisasi realitas yang objektif. Artinya, objektivasi bisa terjadi melalui penyebaran opini sebuah produk sosial yang berkembang di masyarakat melalui diskursus opini masyarakat tentang produk sosial tanpa harus tatap muka antar individu dan pencipta produk sosial itu.

Ketiga, internalisasi merupakan proses penyerapan kembali dunia objektif ke dalam kesadaran individu yang telah dipengaruhi oleh struktur dunia sosial. Melalui internalisasi, manusia menjadi hasil dari masyarakat (Eriyanto, 2002:15-16).

\section{METODE PENELITIAN}

Penelitian ini menggunakan metode studi kasus dengan kriteria tunggal. Kasus tunggal ialah kasus tersebut menyajikan suatu kasus unik dengan situasi umum dalam psikologis klinis, atau kelainan spesifik demikian langka sehingga cukup berharga untuk dianalisis (Robert K.Yin 2015: 48). Objek penelitian ini merupakan kasus langka dan unik yang belum terjadi sebelumnya dalam Pilkada di Banten khususnya Pilkada di Kota Serang dengan mengilustrasikannya secara spesifik.

Pendekatan penelitian menggunakan pendekatan kualitatif yang bertujuan mempertahankan bentuk isi dan perilaku manusia dan menganalisis kualitasnya. dengan paradigma penelitian interpretive. Teknik mengumpulkan data melalui wawancara dan observas. 


\section{HASIL PENELITIAN}

Memahami komunikator politik adalah dengan cara mengidentifikasi kedudukan mereka di dalam masyarakat. Untuk itu diidentifikasi dengan kategori politikus yang bertindak sebagai komunikator politik, dalam hal ini pasangan calon Vera-Nurhasan. Juga komunikator profesional dalam politik yang dianalogikan sebagai mesin politik yaitu partai politik karena cara mereka berpolitik menggunakan cara-cara profesional politisi partai.

Sementara berkaitan dengan pemahaman realitas yang pertama di mana eksternalisasi sebagai bentuk penyesuaian diri dalam ekspresi politik, Vera menghasilkan kejutan-kejutan hasil Pilkada Kota Serang berupa kekalahan Vera-Nurhasan yang didukung oleh koalisai delapan partai politik: Golkar, Gerindra, PDIP, PKB, Demokrat, PKPI, PBB dan Partai Nasdem.

Dilihat dari kekuatan politik yang didukung delapan parpol tersebut, pasangan Vera-Nurhasan sulit terkalahkan, namun realitasnya Vera menempati urutan kedua dalam hasil suara Quick Count maupun KPU.

Kedudukan Vera sebagai istri dari walikota incumbent dua periode sejak tahun 2008 hingga 2018 diprediksi unggul dari pasangan calon lainnya. Statusnya sebagai istri walikota, mempermudah pada jalur "kampanye" melalui progam-program SKPD dengan melibatkan Vera dalam pelaksanaan kegiatannya.

Selain itu, sebagai ipar mantan Gubernur Banten Ratu Atut, ipar Bupati Serang Ratu Tatu, dan tante dari Wakil Gubernur Banten Andika Hazrumy, Vera memiliki posisi strategis untuk meraih suara maksimal dalam konstalasi Pilkada Kota Serang. Vera juga mendapat dukungan luar biasa dari delapan Partai Politik. Namun Vera dinilai merupakan cerminan suaminya, Tb. Hairul Jaman sebagai Walikota Serang yang dalam kepemimpinannya dianggap tidak terlalu berhasil. Tidak ada pembangunan yang signifikan untuk dijadikan modal kampanye. Sementara itu, Nurhasan sebagai politisi lokal dari Gerindra namanya kurang populer di masyarakat dan tidak meninggalkan rekam jejak yang baik sehingga tidak memiliki nilai jual untuk menutupi kelemahan-kelemahan Vera.

Vera sebagai istri walikota petahana mempermudah jalur kampanyenya melalui progamprogram SKPD dengan melibatkan Vera dalam berbagai kegiatan, sehingga interaksi dengan masyarakat dianggap mampu mengangkat elektabilitasnya. Selain itu Vera memanfaatkan Pembinaan Kesejahteraan Keluarga (PKK) Kota Serang yang dikelola istri-istri pejabat Pemerintah Kota Serang. Program kerjanya sebagian besar melakukan sosialisasi dan berkampanye untuk pasangan calon Vera-Nurhasan. Dalam kampanye, Vera banyak menjual program unggulan suaminya yaitu peningkatan infrastruktur kota yang sedang dalam tahap pembangunan.

Dia mengusung jargon "Menuju Kota Serang Cantik" dan mendapat dukungan dari tiga kepala daerah yang juga bagian dari keluarganya: Bupati Serang, Wakil Gubernur Banten, dan Walikota Serang yang juga suaminya. Indikator kegagalan Vera antara lain karena pengalaman politiknya yang dianggap belum maksimal, sementara intensitas kampanye Vera tidak berbekas di kapangan masyarakat.

Konsolidasi partai politik juga dinilai gagal. Partai politik merupakan muara dari kepentingan masyarakat agar kepentingannya diperjuangkan dan menjadi kebijakan negara. Masyarakat yang plural membuat kepentingannya juga beragam. Dalam demokrasi internal, sebuah partai memiliki nilai-nilai dan aturan-aturan yang jelas, terbuka dan dipraktikkan oleh para pemimpin maupun anggota partai tanpa kecuali.

Seringkali kehadiran partai di masyarakat lebih banyak diwakilkan oleh sukarelawan yang terikat dengan partai tertentu, sehingga dengan mudah bagi partai meminta dukungan masyarakat 
p-ISSN: 0853-4470 - Vol. 02, No. 01 (2019), pp. 54-60

manakala musim pemilu tiba. Namun di Indonesia, hampir semua partai terjebak dalam ketergantungan pada figur individu tertentu. Figur tersebut kuat secara personalitas dan finansial. Maka tidak terutup kemungkinan partai asyik dengan perjuangan serta intrik elite-elitenya saja tanpa hadir di tengah tengah masyarakat.

Fenomena tersebut berkaitan dengan apa yang terjadi pada Pilkada Kota Serang dengan kegagalan calon kepada daerah dari kubu keluarga dinasti yang tidak pernah gugur dalam perhelatan demokrasi ini tentu saja menjadi hal yang menarik, sementara dukungan penuh dari sejumlah partai berkuasa menguatkan posisi pasangan Vera-Nurhasan.

Namun karena potensi kekuatan delapan partai politik ini merasa memiliki imunitas tinggi sehingga melemahkan motivasi dalam menganalisis kekuatan lawan politik, delapan Partai pendukung paslon Vera-Nurhasan tersebut adalah Golkar, PDIP, Demokrat, Gerindra, PKB, Partai Nasdem, PKPI, dan PBB.

Koalisi gemuk itulah yang membuat Paslon Vera-Nurhasan kalah. Aksi-aksi politik Vera dianggap kurang optimal karena adanya kemerosotan mental yang terlalu banyak, tekanan-tekanan di dalam kelompok dan melupakan tuntunan kontestasi Pilkada yaitu ketokohan dan figuritas kandidat. Dengan demikian klasifikasi eksternalisasi berlangsung ketika produk sosial tercipta di dalam masyarakat. Produknya adalah pemerintahan dinasti melalui Vera sebagai individu yang menyesuaikan diri dalam dunia politik sebagai bagian dari produk tersebut.

Pesan dalam komunikasi politik dimaksudkan untuk mempengaruhi orang lain. Menurut Nimmo ada tiga klasifikasi pesan dalam komunikasi politik, salah satunya pembicaraan tentang kekuasaan yang dimaksudkan untuk mempengaruhi orang lain dengan janji atau ancaman.

Pada penelitian ini, pesan politik melalui Jargon "Menuju Kota Serang Cantik" pun dianggap tidak ada korelasinya dengan kondisi Kota Serang yang dipimpin Jaman selama dua periode. Visi "Cantik" hanya berpusat pada sosok Vera yang diasosiasikan sebagai wanita cantik. Pada realitasnya kesemrawutan Kota Serang hasil kerja Jaman selama dua periode ditunjukan oleh pembangunan infrastruktur tidak signifikan, peningkatan kemacetan kendaraan di jalan-jalan protokol, menjamurnya persaingan mini market hampir di seluruh penjuru kota yang melemahkan perdagangan warung-warung kecil di sekitarnya.

Pada H-1 Pencoblosan terjadi banjir di beberapa titik di Kota Serang sehingga menenggelamkan kata "Cantik" yang diusung Vera. Dengan demikian Vera sebagai individu melakukan objektivasi terhadap produk sosial artinya melalui penyebaran opini melalui jargon "Menuju Kota Serang Cantik" sebagai produk sosial dari pemerintah dinasti yang berkembang di masyarakat melalui diskursus opini masyarakat tanpa harus terjadi tatap muka antar individu.

Khalayak dalam komunikasi politik dalam penelitian ini adalah khalayak atentif, khalayak berpikiran isu, khalayak ideologis. Khalayak atentif atau juga disebut publik atentif merupakan kumpulan warga negara yang sering disebut sebagai pemuka pendapat yang selalu dimintai pendapatnya oleh masyarakat yang kurang informasi dalam politik, seperti para politisi yang ada di Kota Serang. Khalayak berpikiran isu adalah khalayak yang memusatkan perhatian pada isu tertentu yang tidak ada dalam kelompok formal seperti para akademisi, aktivis (LSM), mahasiswa dan lainlani, sementara khalayak ideologis menganut nilai yang logis seperti para ibu rumah tangga, pedagang, dll.

Terkait Pilkada Kota Serang, partisipasi pemilih di Kota Serang di luar dugaan. Berdasarkan data KPU Kota Serang yang mencapai 69,62 persen dari daftar pemilih tetap (DPT) sebanyak 422.072 jiwa. Pasangan Vera-Nurhasan yang berhasil mendapat dukungan delapan partai sekaligus menjadi musuh bersama para pendukung pasangan lainnya yang tidak mendapat kendaraan politik sebanyak 
p-ISSN: 0853-4470 - Vol. 02, No. 01 (2019), pp. 54-60 itu. Belum lagi pasangan pemenang Pilkada Syafrudin-Subadri adalah orang-orang yang maju di kancah Pilkada berawal dari kekecewaan. Syafrudin adalah mantan birokrat yang tidak mendapat tempat di mata Walikota Serang Tb Hairul Jaman, sementara Subadri adalah mantan anggota partai Golkar yang dipecat dari partainya. Kondisi tersebut melalaikan tim sukses Vera-Nurhasan bahwa berawal dari kekecewaan menumbuhkan unsur radikal bebas yang mampu menggerakan sikap politik para undecided voters, menjadi kekuatan besar kemudian mampu membalikkan angka kemenangan bagi Syafrudin-Subadri dan tingginya suara calon independen yang berdampak pada tingkat partisipasi pemilih.

Mereka menjadi kekuatan besar yang bersepaham untuk mengeliminasi lawan yang sama. Tujuannya menggunakan pemilu sebagai wahana protesnya dengan mengalihkan pilihannya untuk melawan kandidat yang tidak disukainya. Hal tersebut ditunjukkan dengan perolehan suara pasangan Syafrudin-Subadri dan Samsul-Rohman (calon independent) yang mampu meredam Vera-Nurhasan di wilayah perkotaan, yakni Kecamatan Serang dan Cipocok Jaya, dua basis pemilih rasional terbesar di Kota Serang.

Menurut Berger dan Luckmann dalam Bungin (2006:205), dalam tahap internalisasi sosialisasi tidak pernah lengkap karena selalu ada tantangan untuk memelihara realitas, khususnya memelihara realitas subjektif dan realitas objektif. Kegagalan sosialisasi pasangan calon walikota Vera-Nurhasan dalam Pilkada Kota Serang karena tidak memelihara realitas bahwa cara berfikir masyarakatnya berkembang pesat tanpa menggantungkan status politiknya pada calon-calon yang masih dalam lingkaran pemerintahan dinasti.

\section{KESIMPULAN}

Kesimpulan penelitian ini adalah imunitas Vera sebagai calon Walikota Serang yang juga istri Walikota incumbent, serta Nurhasan seorang pengusaha sekaligus politisi Partai Gerindra dengan intensitas kampanye melalui program-program SKPD, ditambah dukungan delapan partai politik, tidak menjamin kemenangan Vera-Nurhasan.

Sebagai komunikator politik, Vera belum cakap berpolitik apalagi memahami situasi pemerintahan Kota Serang. Vera juga dianalogikan sebagai bayang-bayang Tb. Hairul Jaman yang dianggap belum membawa pembangunan yang signifikan bagi Masyarakat Kota Serang. Sedangkan konsolidasi delapan partai politik dinilai gagal karena mereka lemah menganalisis kekuatan lawan politik.,Pesan politik yang diusung tim Vera-Nurhasan dengan Jargon "Menuju Kota Serang Cantik" dinilai kurang tepat karena tidak mencerminkan kondisi Kota Serang yang sebenarnya dengan kesemrawutan infrastrukturnya.

Para pemilih yang merupakan khalayak perkotaan ternyata rasional dengan membandingkan perkembangan infrastruktur maupun kesejahteraan masyarakatnya dengan wilayah perkotaan lain. Khalayak ini bukan lagi khalayak yang loyal terhadap pemerintahan dinasti dengan mempertahankan mitos keberadaannya, namun khayalak yang berpartisipasi serta bertindak dalam perpolitikan Kota Serang dengan mengedepankan rasionalitas terhadap realitas kualitas kepemimpinan sebelumnya.

\section{Daftar Pustaka}

Bungin, Burhan. (2006). Sosiologi Komunikasi. Jakarta: Fajar Interpratama Mandiri Eriyanto. (2002). Analisis Framing Konstruksi, Ideologi, Dan Politik Media. Jakarta. LKis Harun \& Sumarno. (2006). Komunikasi Politik Sebagai Suatu Pengantar. Bandung: Penerbit Mandar Maju.

K.Yin. Robert. (2015). Metode Penelitian Studi Kasus. Jakarta.:Raja Grafindo Persada. 
p-ISSN: 0853-4470 - Vol. 02, No. 01 (2019), pp. 54-60

Nimmo. Dan. (2010). Komunikasi Politik Khalayak dan Efek. Jakarta: Remaja Rosdakarya.

Riswandi. 2009. Ilmu Komunikasi. Jakarta: Penerbit Graha Ilmu 